\title{
Popular justice on bullies: Attributions of responsibility, anger, and ineffective social control as fuel for non-normative collective action
}

\author{
Miguel Campos ${ }^{1}$, André G. Marques², Tiago Aguiar ${ }^{1}$, Sónia G. Cardoso ${ }^{3}$, Isabel R. Pinto ${ }^{13}$ \\ \& José M. Marques ${ }^{13}$ \\ ${ }^{1}$ Faculty of Psychology and Educational Sciences, University of Porto \\ ${ }^{2}$ School of Psychology, University of Kent \\ ${ }^{3}$ Institute of Social Sciences, University of Lisbon
}

\begin{abstract}
School bullying has seldom been analyzed through the perspective of society in general. However, severe collective reactions often emerge towards bullies when they attract public attention. In this paper, we analyze the process underlying these non-normative forms of collective action triggered by bullying. A survey was presented to 350 Portuguese participants following the release of a viral video depicting a bullying situation. Results showed that assignment of responsibility to the aggressor predicted agreement with popular justice, which was mediated by anger and moderated by perceived ineffectiveness of social control. Specifically, greater responsibility attributed to aggressors yielded greater anger towards them, which, in turn, triggered more agreement with popular justice. Moreover, this effect was stronger for participants who believed that formal social control mechanisms were ineffective. We discuss these results in light of their contribution for tackling bullying, as well as for the literature on deviance, social control and collective action.
\end{abstract}

Keywords: Bullying; Social control; Collective action; Popular justice; Reaction to deviance.

Justiça popular em bullies: Atribuições de responsabilidade, raiva, e controlo social ineficaz como combustível para ação coletiva não-normativa: 0 bullying escolar raramente tem sido analisado através do ponto de vista da sociedade em geral. No entanto, nas situações em que o agressor atrai a atenção mediática, verificam-se reações coletivas muito severas. Neste trabalho, analisámos os processos subjacentes à ação coletiva não-normativa que muitas vezes emerge perante situações de bullying. Após um vídeo amador que mostrava uma destas situações se ter tornado viral em Portugal, pedimos a 350 participantes que preenchessem um questionário sobre o tema. Os resultados mostraram que a atribuição de responsabilidade ao agressor predizia a concordância com medidas de justiça popular, e que isto era mediado por emoções de raiva, e moderado pela perceção de ineficácia dos mecanismos de controlo social. Mais especificamente, quanto maior a responsabilidade atribuída ao agressor, maior a raiva sentida, o que levava a um maior grau de concordância com medidas de justiça popular. Para além disso, este efeito era maior para os participantes que acreditavam que os mecanismos formais de controlo social eram ineficazes. Os resultados foram discutidos à luz da sua contribuição para o combate ao bullying, e da literatura sobre desvio, controlo social, e ação coletiva.

Palavras-chave: Bullying; Controlo social; Ação coletiva; Justiça popular; Reação ao desvio.

In May 2015, the Portuguese media and social networks were flooded with a viral video in which a teenage girl, surrounded by her friends, physically abused a defenseless teenage boy. During the 13 minutes of video, the boy passively received 30 slaps, 11 punches and 2 kicks. This case generated feelings of anger and outrage in the general public, and triggered a wave of solidarity with the victim. Interestingly, many people also reported their willingness to punish the bully, ranging from mere expression of indignation on social media to more raging actions, such as revealing private information about the aggressor and vowing to punish her proportionally to the suffering she caused to the victim. It appeared that everyone was interested in restoring justice by their own hands in the days that followed the release of the footage.

It was precisely this general motivation that captured our attention and inspired us to conduct the present study. Why did some people feel the need to take justice into their own hands? In the present paper we argue that assigning responsibility to bullies should trigger anger towards them, culminating in

${ }^{1}$ Address for correspondence: Miguel Campos, Social Psychology Research Group, Faculty of Psychology and Educational Sciences, University of Porto, R. Alfredo Allen, P-4200-135, Porto, Portugal. E-mail: mcampos@fpce.up.pt. 
a stronger agreement with popular justice - a non-normative collective action of punishment. Furthermore, we propose that such punitive action is more likely to occur as a compensatory response for the perceived ineffectiveness of formal social control mechanisms aimed to prevent and to sanction bullying.

\section{Bullying as a social problem}

Although only specific cases reach the media and gather general awareness, bullying in schools has increasingly become a focus of concern for educators and social policy-makers (Hymel, Schonert-Reichl, Bonnano, Vaillancourt, \& Rocke Henderson, 2010). For example, a cross-national study involving 27 countries found that, among 13 year-old pupils, between $1 \%$ and $10 \%$ admitted they had bullied others at least once a week during the school term. This percentage rose to an alarming $12 \%$ to $64 \%$ of teenagers who admitted that they have occasionally bullied others during the same period (Krug, Dahlberg, Mercy, Zwi, \& Lozano, 2002). In Portugal, 38,7\% of pupils reported that they had been provoked by others at school at least on a weekly basis, whereas 30,9\% admitted that they regularly provoked their schoolmates (Matos, Simões, Camacho, Reis, \& Equipa-Aventura-Social, 2015).

Bullying can have short- and long-term consequences for both victims and bullies (Adams \& Lawrence, 2011; Gini \& Pozzoli, 2009; Olweus, 1991, 1994). For example, victims of bullying may experience anxiety, depression, psychological distress, physical illness symptoms, eating disorders, poor social adjustment, or school absenteeism in the short-run, and they may never fully recover from these effects in later life stages (Rigby, 2003; Smokowski \& Kopasz, 2005). On their side, school bullies are more likely to have criminal records in the future, particularly for violent crimes (Olweus, 1991).

Traditionally, bullying has been analyzed through the perspectives of the bullies (e.g., Baldry \& Farrington, 2000; Olweus, 1978), of the victims (e.g., Green, Collingwood, \& Ross, 2010; Theriot, Dulmus, Sowers, \& Johnson, 2005), or of the (potential) bystanders of bullying situations (e.g., Correia, Alves, Almeida, \& Garcia, 2010; Obermann, 2011; Thornberg \& Jungert, 2013). We believe that the perspective of the general public should also be considered in order to effectively tackle this social problem. Indeed, society in general (including family, teachers, policy-makers, and others) plays a significant role in having children and adolescents understand the consequences of these aggressive behaviors. This is especially important when considering that repeated exposure to bullying may increase children's tolerance to it, because they progressively perceive the aggressions as less immoral (Hymel \& Bonanno, 2014). As these bullying cases gather more attention and become more salient, people's perception about the effectiveness of the formal mechanisms responsible for dealing with such problems may wane. Some people may not even be aware of the existing mechanisms responsible for dealing with bullying. As a means to compensate for this perceived absence, or ineffectiveness, of social control mechanisms, individuals may be prompted to take measures, including informal collective action (Strelan \& van Prooijen, 2013). Given that bullying is generally considered a deviant behavior, and because literature on reaction to deviance has recently shifted their focus to the effects of the social control mechanisms on the reactions towards deviant members, this literature should provide a pertinent framework for a better comprehension of this phenomenon.

\section{Deviance and social control mechanisms}

There is compelling evidence that individuals are particularly derogative towards members of their group who act in a deviant way (Marques \& Páez, 2008; Marques, Yzerbyt, \& Leyens, 1988; cf. also Jetten \& Hornsey, 2014, for a review). According to sociologist Émile Durkheim (1893), deviance is an important even indispensable - mechanism for maintaining cohesion in society. Based on this approach, scholars have demonstrated that by expressing outrage and disapproval regarding deviance, normative members increase their compliance with the group's normative system, and reinforce their solidarity to the group (e.g., Erikson, 1962; Garland, 1996; Gibbs, 1977; Hamilton \& Rauma, 1995; Harris \& Hill, 1982; Inverarity, 1980). Similarly, Marques and colleagues (Marques, Abrams, Páez, \& Hogg, 2001; Marques \& Páez, 2008; Pinto, Marques, Levine, \& Abrams, 2010) sustain that reacting to deviant ingroup members allows individuals to increase their adherence to the violated norm (Pinto, Marques, Levine, \& Abrams, in press) and to restore a legitimated positive social identity (Marques \& Páez, 2008).

In line with this idea, in a recent set of studies, Pinto, Marques, and Páez (2015) have shown that participants who believed that their country was effective in detecting and punishing criminals reported higher hope and optimism about that country's prospects, more positive related emotions and, ultimately, a stronger national identification than did participants who believed that the country's social control mechanisms were ineffective. However, there is also evidence that disbelief in the group's ability to control deviance may lead normative members to try and compensate for the frailty of social control mechanisms, by engaging in informal punitive action against the deviants, as a mean to restore a sense of 
justice and a positive ingroup image (Carlsmith \& Darley, 2008; Carlsmith, Darley, \& Robinson, 2002; Marques, Abrams, \& Serôdio, 2001; Strelan \& van Prooijen, 2013). By engaging in compensatory punishment, group members should increase their well-being, their commitment to the group's normative positions, and their self-definition as ingroup members (De Rivera \& Páez, 2007; Fredrickson, 2009; Marques, Abrams, Páez, \& Martinez-Taboada, 1998; Sani, Bowe, Herrera, Manna, Cossa, Miao, \& Zhou, 2007; Swann, Gómez, Seyle, Morales, \& Huici, 2009).

\section{Non-normative collective action}

Collective action can take various forms (for a review, cf. Becker \& Tausch, 2015). Tausch and colleagues (2011) differentiate between normative forms of collective action (i.e., actions taken through generally accepted channels, such as political participation or organized peaceful protests) and non-normative actions (i.e., actions taken through unaccepted ways, such as violence or terrorism). The authors argue that non-normative collective action is more likely to arise when individuals feel that their group is powerless in addressing some social issue and in influencing the authorities that have primary responsibility to deal with that issue (cf. van Zomeren, Postmes, \& Spears, 2008). Furthermore, through these intense informal punitive reactions, the group may still achieve a sense of justice (Strelan \& van Prooijen, 2013). Therefore, support for non-normative collective actions (e.g., popular justice) may function as a compensatory mechanism to deal with the perceived ineffectiveness of formal social control mechanisms (Marques, Pinto, Leite, Randsley de Moura, Van Prooijen, \& Marques, under review).

Non-normative collective action is often driven by strong negative emotions, particularly anger and contempt, the former being usually associated with short-term outrage, and the latter predicting longer lasting feelings of injustice (Becker \& Tausch, 2015). Although Becker and Tausch (2015) argue that non-normative collective actions are motivated by contempt, they also highlight that anger predicts spontaneous and impulsive aggressive behaviors (cf. van Stekelenburg, Klandermans, \& van Dijk, 2011). Attribution of blame to an external person or entity is also an important trigger of collective actions (Javeline, 2003; Simon \& Klandermans, 2001). In addition, attributions of this kind are often paired with feelings of anger (Quigley \& Tedeschi, 1996).

\section{OVERVIEW AND HYPOTHESES}

In the present study, we focus on one particular manifestation of non-normative collective action (cf. Tausch et al., 2011): the willingness to take justice into one's own hands, as is the case of the so-called "lynching" or "popular justice". According to de la Roche (1996), this kind of collective action differs from other types of collective aggression in two dimensions: liability (i.e., groups or individuals are accountable for their wrongdoing) and organization (i.e., actions are relatively spontaneous and unorganized). Throughout this paper, we will refer to this manifestation of non-normative collective action as popular justice.

We believe that, in the case of bullying, people may be prone to engage in popular justice. First, popular justice requires assignment of blame to a person or entity (de la Roche, 1996; cf. also Javeline, 2003; Simon \& Klandermans, 2001). Because society in general considers bullying as deviant behavior, responsibility for such deviant acts should be particularly attributed to the aggressors. Second, both the assignment of blame (Quigley \& Tedeschi, 1996) and the adherence to collective action (Becker \& Tausch, 2015; van Stekelenburg et al., 2011) are associated with feelings of anger. Finally, people may not be entirely aware of the social control measures that are predicted to be implemented when cases of bullying occur or believe that these mechanisms are ineffective in dealing with them. Therefore, popular justice may emerge as an alternative compensatory action to exert social control, either to help address the problem when authorities fail to do so (van Zomeren et al., 2008), or to achieve a sense of justice (Strelan \& van Prooijen, 2013).

Specifically, we expect that the more participants assign blame to the bullies, the more they will agree with punitive collective action (i.e., popular justice) towards the aggressors to the extent that the situation triggered feelings of anger in the participants. Finally, anger should lead to agreement with popular justice, especially when participants perceive the group to be ineffective in controlling bullying. In brief, we propose a moderated-mediation regression model, in which attribution of responsibility for the bullying behavior to the aggressors is the predictor variable, agreement with popular justice is the dependent variable, and anger and perceived effectiveness of social control are, respectively, the mediator and the moderator. 


\section{METHOD}

\section{Participants}

Participants were 350 Portuguese citizens (92 men and 258 women) who agreed to answer an online survey conducted through email and social network websites. Participants' age ranged from 18 to $71(M=$ $24.71, S D=7.96)$. All participants gave their informed consent before answering the questionnaire, and were told they were free to abandon their participation in the study anytime.

\section{Materials and Procedure}

The survey was conducted in the days that followed the release of a video footage featuring a blatant bullying episode which took place close to a secondary school in Portugal, in which a teenage girl brutally assaulted a boy while surrounded by her schoolmates. The video went viral and was subject of thorough discussion in the social media and networks. In order to frame the study, the survey initially highlighted that bullying in schools was an important problem and that the present research was aimed at better understanding that phenomenon. No direct reference to the particular bullying case was made throughout the study.

We first asked participants to think about any bullying episodes that they knew personally and to indicate to whom they assigned responsibility for the occurrence of such episodes, how angry they felt towards bullies, how effective they perceived the formal authorities to be in detecting and judging those cases, and how much they agreed with handling this problem through popular justice. Finally, we collected some demographics and thanked participants for their collaboration.

\section{Measures}

\section{Attribution of Responsibility}

Participants reported to what extent they considered different persons or entities to be responsible for the occurrence of school bullying ( 1 = I completely disagree, 7 = I completely agree): "The school"; "The parents of the victims"; "The parents of the aggressors"; "The victims"; and "The aggressors".

\section{Anger}

We measured anger by asking participants how much anger they felt towards the aggressors in bullying situations (1 = None; 7 = Very much).

\section{Perceived Effectiveness of Social control}

Three items tapped on participants' beliefs about the authorities' effectiveness in dealing with the bullying phenomenon ( 1 = I completely disagree, 7 = I completely agree): "I believe that the authorities are capable of doing justice in cases of bullying"; "The measures adopted by the authorities are sufficient to deal with bullying cases"; "The measures adopted by the authorities are sufficient to detect bullying cases". We averaged these items' scores to a Perceived Effectiveness of Social Control index (Cronbach's $\alpha$ $=.81)$.

\section{Agreement with Popular Justice}

Four items tapped participants' agreement with popular justice $(1=$ I completely disagree, $7=$ I completely agree): "Sometimes it is better to take justice into one's own hands"; "People should organize themselves in order to physically punish the aggressors"; "Sometimes, popular justice is the best option"; "Popular justice would be the most adequate solution for cases like these". We averaged these items' scores to an Agreement with Popular Justice index (Cronbach's $\alpha=.90)$.

\section{RESULTS}

\section{Measures}

\section{Attribution of Responsibility}

Descriptive results on Attribution of Responsibility scores show that participants believe that the aggressors are the most accountable for bullying situations (in all comparisons between Aggressors' Responsibility and all other responsibility factors, $p$ always $<.001$ ); see Table 1 . In addition, we conducted a multiple linear regression analysis in order to ascertain which type of attribution accounted for higher variability in Agreement with Popular Justice. As expected, results show that Aggressors' Responsibility was the only significant predictor of Agreement with Popular Justice, $\beta=.15, t=2.71, p=$ .007 (for all other factors, $\beta \leq .11, t \leq 1.75, p \geq .081$ ). 
Table 1. Means and standard deviations for the Attribution of Responsibility items.

\begin{tabular}{lll}
\hline Attribution of Responsibility & $\boldsymbol{M}$ & $\boldsymbol{S D}$ \\
\hline The school & 3.84 & 1.59 \\
The parents of the victims & 2.27 & 1.33 \\
The parents of the aggressors & 4.98 & 1.38 \\
The victims & 2.02 & 1.30 \\
The aggressors & 6.31 & 1.07 \\
\hline
\end{tabular}

\section{Anger}

A one sample $t$-test showed that the score of Anger was significantly higher than 4 , the scale midpoint ( $M$ $=5.09, S D=2.03), t(349)=10.05, p<.001)$, indicating that bullying cases trigger great levels of anger in participants.

\section{Perceived Effectiveness of Social Control}

In line with our expectations, participants perceived formal social control measures of bullying cases in the country to be ineffective. Indeed, a one sample $t$-test conducted on the Perceived Effectiveness of Social Control score revealed significantly low values $(M=2.76, S D=1.13), t(349)=-20.67, p<.001$, as compared to the mid-point of the scale (4).

\section{Agreement with Popular Justice}

Finally, participants reported low Agreement with Popular Justice $(M=2.28, S D=1.36)$. This is not surprising, considering that the items measuring this, are of an extreme punitive nature and are directed at bullies in schools who are, still, fundamentally children and teenagers. Although we had no specific expectations regarding this relatively low score, it is reasonable to suppose that participants consider engagement in informal punishment as a generally socially undesirable conduct.

\section{Mediation Analyses}

We propose a moderation-mediation regression model in which Aggressors' Responsibility is the predictor, Agreement with Popular Justice is the dependent variable, Anger is the mediator, and Perceived Effectiveness of Social Control is the moderator of the association between Anger and Agreement with Popular Justice. We expected that the more the aggressor is perceived to be responsible for the bullying behavior, the higher should be the participants' level of anger. In turn, the angrier participants feel towards the aggressor, the more agreement with popular justice they should report. This association should, nevertheless, be stronger for participants who consider institutional mechanisms of social control to be ineffective than for participants who report more confidence in these mechanisms.

\section{Mediation role of Anger on the association between Aggressors' Responsibility and Agreement with Popular Justice and Moderation role of Perceived Effectiveness of Social Control}

We first conducted Pearson's product-moment correlations between the measures that compose our model. As expected, all are significant; see Table 2.

Table 2. Pearson Correlation Matrix for measures included in the Mediated-Moderation Model.

\begin{tabular}{|c|c|c|c|}
\hline & 2 & 3 & 4 \\
\hline 1. Aggressors' Responsibility & $.29 * * *$ & -.09 & $.14^{* *}$ \\
\hline 2. Anger & - & $-.20 * * *$ & $.31^{* * *}$ \\
\hline 3. Perceived Effectiveness of Social Control & - & - & $-.21^{* * *}$ \\
\hline 4. Agreement with Popular Justice & - & - & - \\
\hline
\end{tabular}

Note. ${ }^{* * *} p<.001 ;{ }^{* *} p<0.01 ;{ }^{*} p \leq .05$

This correlations pattern allows us to proceed with the moderated-mediation analysis. Thus, we tested our proposed model (PROCESS; Model 14, with 10,000 bootstrap; see Hayes, 2013). This model (see Figure 1) significantly explained Agreement with Popular Justice, $F(4,345)=15.11, p<.001$, and accounted for $14.90 \%$ of the total variance. In line with our prediction, the moderated-mediation model is statistically significant (index of moderated-mediation $b=-0.06, S E=0.02,95 \% \mathrm{CI}=[-0.11,-0.03]$ ). Moreover, Perceived Effectiveness of Social Control significantly interacts with Anger in predicting Agreement with Popular Justice (interaction effect between the mediator and the moderator: $b=-0.11, S E$ $=0.03, t=-3.59, p<.001,95 \% \mathrm{CI}=[-0.17,-0.05])$. This interaction shows that the mediating effect is relevant for participants that most perceived the group to be ineffective in dealing with bullying (-1SD, $b$ $=0.18, \mathrm{SE}=0.04,95 \% \mathrm{CI}=[0.11,0.27]$, but not for participants with high perceived efficacy $[1 \mathrm{SD}, \mathrm{b}=$ 
$0.04, \mathrm{SE}=0.03,95 \% \mathrm{CI}=[-0.09,0.09])$. As expected, the model fully accounts for the association between Aggressors' Responsibility and Agreement with Popular Justice (direct effect: $b=0.04, S E=0.07, t<1$ ). In brief, a stronger responsibility attributed to aggressors yields more anger towards them, which, in turn, triggers more agreement with popular justice. Moreover, this effect is stronger for participants who believe that formal social control mechanisms are ineffective.

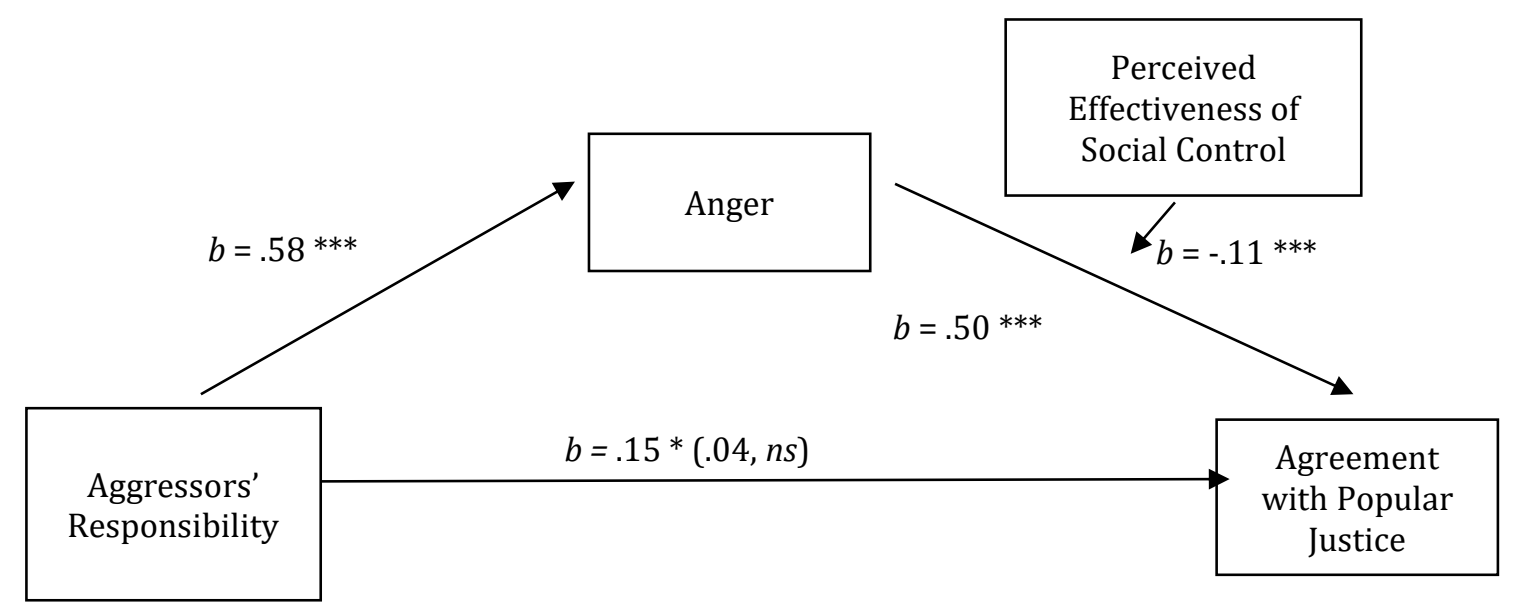

Note. ${ }^{* * *} p<.001 ;{ }^{* *} p<0.01 ;{ }^{*} p \leq .05$

Figure 1. Model testing the hypothesis that Anger mediates the association between Aggressor Responsibility and Agreement with Popular Justice, with Perceived Effectiveness of Social Control acting as the moderator.

\section{DISCUSSION}

In the present work, we were interested in studying the processes underlying the collective punishment of bullies. We argued that agreement with popular justice is fueled by the attribution of responsibility to aggressors, the anger directed at them, and the perceived ineffectiveness of social control mechanisms in dealing with this issue. Overall, the findings are consistent with our hypotheses. Firstly, our results showed that, although people may perceive other factors to account for bullying, they considered aggressors as the most responsible among the persons or institutions that play a direct or indirect role in the bullying phenomenon. Secondly, results supported the idea that bullying is associated with anger directed at the aggressors, and that such anger interacts with the perceived ineffectiveness of formal social control mechanisms. Indeed, greater levels of anger towards aggressors predicted higher agreement with popular justice, especially when people believed that formal social control mechanisms were not effective.

From a more general standpoint, the present findings may shed further light on the processes underlying deviance, social control and collective action, as well as contribute to better comprehend and tackle bullying.

\section{Social control of deviance and collective action}

Our findings extend prior knowledge regarding the importance of effective social control mechanisms. Pinto and colleagues (2015) had already posited that the perception that formal mechanisms of social control are ineffective in dealing with deviance triggers negative outcomes for both individuals and groups, in the sense that they perceive the group as more anomic, perceive the future with less hope and optimism, and decrease their bonds with the group. However, and in line with literature that proposes that ineffective social control may lead to the adoption of compensatory action (e.g., Carlsmith \& Darley, 2008; Carlsmith et al., 2002; Strelan \& van Prooijen, 2013), our findings suggest that popular justice may be a relevant group response to take into account in research on compensatory action. Indeed, participants in our study were more willing to advocate popular justice towards the aggressors the more they perceived the social control system as ineffective in preventing and sanctioning bullying. Importantly, popular justice refers to taking justice into ones' own hands, which suggests that participants were interested in sanctioning a behavior that would, otherwise, remain unpunished. This idea fits the functionalist approach to deviance (Durkheim, 1893; cf. also Marques \& Páez, 2008), in the sense that participants appeared to believe that punishing deviants was necessary to maintain social order and restore justice, a core value to national groups. 
The present study also contributes to the understanding of the emergence of non-normative collective action. As noted before, collective action can take various forms, including normative and nonnormative forms (Becker \& Tausch, 2015; Tausch et al., 2011). In this paper, we focused on one example of non-normative collective action: the agreement with popular justice, which requires attribution of liability to the aggressor and a spontaneous collective movement (de la Roche, 1996). We considered it as the willingness to compensate for the absence of an effective means to maintain social order, although done through potentially violent means. The mediated-moderation found in this work also fits with literature that suggests that non-normative collective actions should be associated with anger (Becker \& Tausch, 2015), and that this anger should be channeled to collective action when individuals feel powerless in having authorities properly address the issue in question (van Zomeren et al., 2008).

Importantly, our study reinforces the need to pursue a thorough study of popular justice manifestations. As far as we know, popular justice is a topic that does not capture much attention among scholars, particularly in the social psychological domain. However, it is a phenomenon that does, indeed, occur, as illustrated by our study and by the case that introduced this paper. Moreover, the expansion of internet and social media may provide new contexts for the engagement in collective action, and namely, in popular justice (for a review, cf. Spears \& Postmes, 2015). Because of its recent nature, internet and social media phenomena, such as online activism, are still understudied. Indeed, there is evidence that the so-called new media (e.g., social networks) provide a depersonalized context (Postmes, 2009; Spears \& Postmes, 2015) that allows immediate and interactive communication, which can ultimately lead to collective action (Castells, 2015), and more specifically to cyberhate (Douglas, 2009). For these reasons, harsh manifestations of popular justice, as well as other non-normative types of collective action, should receive greater attention from academics.

\section{Tackling the social problem of bullying}

Researchers working on bullying acknowledge it as a complex social problem, and often recommend a holistic analysis of the issue, not restricted to the bullies, to the victims, or to the bystanders (e.g., Hymel, Rocke-Henderson, \& Bonanno, 2005; Smith, Pepler, \& Rigby, 2004; Swearer \& Doll, 2001; Vernberg \& Biggs, 2010). In addition, other researchers suggest that greater exposure to bullying can increase the perception of this behavior as less immoral - thus more acceptable - among children and adolescents (Gini, 2006). This, in turn, not only affects youngsters' attitudes towards bullies (Almeida, Correia, \& Marinho, 2009), but also increases the likelihood of more bullying in the future (Hymel \& Bonanno, 2014), and decreases the likelihood of peers intervening to defend victims from aggressions (Obermann, 2011).

Our study complements the aforementioned literature by showing that broader societal characteristics can have a relevant role in controlling and responding to bullying. According to our results, bullying is, indeed, an overall deviant, unacceptable behavior which generates great outrage and anger among people, particularly directed at bullies. The consensually-shared conscience of how unacceptable such behaviors are, if successfully conveyed to children and adolescents, may contribute to increase the perception of immorality of such acts and, in the long run, decrease the prevalence of this phenomenon. We expect our work to contribute to help tackling this social problem.

\section{Limitations and future studies}

The present study has some limitations that should be addressed in future studies on this subject. Particularly, although we are confident that the majority of participants evoked the specific case of bullying that was salient at the time of data collection, the task instructed participants to evoke cases of bullying that they were aware of. For this reason, we cannot assume that participants evoked the same event, which may have influenced our results. Another limitation is that the questionnaire did not offer an option to ascribe blame to bystanders, who are frequently present in bullying situations and were also present in the event that inspired this study. Because of their passiveness in performing immediate social control over the aggressors, bystanders might also share blame for these bullying situations. Finally, because blaming the victim is a common psychological phenomenon, future studies could also assess the emotions directed at the victims, and analyze whether blaming them has an impact on collective action.

\section{CONCLUSIONS}

Based on the present work, as well as on the literature on collective action (e.g., de la Roche, 1996), popular justice appears to be the last resort to restore social order. This is particularly problematic for bullying, considering that aggressors are, fundamentally, children and adolescents, most of them underage and, thus, legally unaccountable for their actions. Our work suggests that prevention of positive attitudes towards popular justice could be achieved by developing legislation aimed at formally 
sanctioning bullies, regardless of their age. Also importantly, society should be aware of the existing formal mechanisms of social control, as well as of their effectiveness. We suggest, thus, that formal authorities put greater effort in conveying the message that bullying does not go unpunished.

To conclude, the aim of our paper was to understand how bullying, a phenomenon with increasing awareness, can provoke agreement with popular justice actions aimed at compensating for the ineffectiveness of social control of bullying. Our findings highlighted not only the pertinence in considering the society's perspective in general to properly address the issue of bullying, but also the need to pursue the scientific study of popular justice as a non-normative form of collective action.

\section{REFERENCES}

Adams, F. D., \& Lawrence, G. J. (2011). Bullying victims: The effects last into college. American Secondary Education, $40(1), 4$.

Almeida, A., Correia, I., \& Marinho, S. (2009). Moral Disengagement, Normative Beliefs of Peer Group, and Attitudes Regarding Roles in Bullying. Journal of School Violence, 9(1), 23-36. http://dx.doi.org/10.1080/15388220903185639

Baldry, A. C., \& Farrington, D. P. (2000). Bullies and delinquents: personal characteristics and parental styles. Journal of Community \& Applied Social Psychology, 10(1), 17-31. http://dx.doi.org/10.1002/(SICI)1099-1298(200001/02)10:1<17::AID-CASP526>3.0.CO;2-M

Becker, J. C., \& Tausch, N. (2015). A dynamic model of engagement in normative and non-normative collective action: Psychological antecedents, consequences, and barriers. European Review of Social Psychology, 26(1), 43-92. http://dx.doi.org/10.1080/10463283.2015.1094265

Carlsmith, K. M., \& Darley, J. M. (2008). Psychological Aspects of Retributive Justice. Advances in experimental social psychology (Vol. 40, pp. 193-236): Academic Press. https://doi.org/10.1016/S0065-2601(07)00004-4

Carlsmith, K. M., Darley, J. M., \& Robinson, P. H. (2002). Why do we punish?: Deterrence and just deserts as motives for punishment. Journal of Personality and Social Psychology, 83(2), 284-299. http://dx.doi.org/10.1037/0022-3514.83.2.284

Castells, M. (2015). Networks of outrage and hope: Social movements in the Internet age. Cambridge: Polty Press.

Correia, I., Alves, H., Almeida, A., \& Garcia, D. J. (2010). Norms regarding secondary victimization of bullying victims: Do they differ according to the victim's categorization? Scandinavian Journal of Psychology, 51(2), 164-170. http://dx.doi.org/10.1111/j.1467-9450.2009.00732.x

de la Roche, R. S. (1996). Collective violence as social control. Sociological Forum, 11(1), 97-128. http://dx.doi.org/10.1007/bf02408303

De Rivera, J., \& Páez, D. (2007). Emotional Climate, Human Security, and Cultures of Peace. Journal of social issues, 63(2), 233-253. http://dx.doi.org/10.1111/j.1540-4560.2007.00506.x

Douglas, K. M. (2009). Psychology, discrimination and hate groups online. In A. Joinson, K. McKenna, T. Postmes, \& U.-D. Reips (Eds.), The Oxford Handbook of Internet Psychology (pp. 155-164). Oxford: Oxford University Press. http://dx.doi.org/10.1093/oxfordhb/9780199561803.013.0011

Durkheim, É. (1893). La division du travail social: Étude sur l'organisation des societés supérieures. Paris, France: Félix Alcan.

Erikson, K. T. (1962). Notes on the Sociology of Deviance. Social Problems, 9(4), 307-314. http://dx.doi.org/10.2307/798544

Fredrickson, B. (2009). Positivity. New York: Crown.

Garland, D. (1996). Social control. In A. Kuper \& J. Kuper (Eds.), The social science encyclopedia (pp. 780783). London, UK: Routledge.

Gibbs, J. P. (1977). Social Control, Deterrence, and Perspectives on Social Order. Social Forces, 56(2), 408423. http://dx.doi.org/10.1093/sf/56.2.408

Gini, G. (2006). Social cognition and moral cognition in bullying: what's wrong? Aggressive behavior, 32(6), 528-539. http://dx.doi.org/10.1002/ab.20153

Gini, G., \& Pozzoli, T. (2009). Association between bullying and psychosomatic problems: a meta-analysis. Pediatrics, 123(3), 1059-1065. http://dx.doi.org/10.1542/peds.2008-1215

Green, R., Collingwood, A., \& Ross, A. (2010). Characteristics of bullying victims in schools. UK: National Centre for Social Research.

Hamilton, V. L., \& Rauma, D. (1995). Social psychology of deviance and law. In K. S. Cook, G. A. Fine, \& J. S. House (Eds.), Sociological perspectives on social psychology (pp. 524-547). Boston, MA: Allyn \& Bacon.

Harris, A. R., \& Hill, G. D. (1982). The Social Psychology of Deviance: Toward a Reconciliation with Social Structure. Annual Review of Sociology, 8, 161-186. 
Hayes, A. F. (2013). Introduction to mediation, moderation, and conditional process analysis: A regressionbased approach: Guilford Press.

Hymel, S., \& Bonanno, R. A. (2014). Moral Disengagement Processes in Bullying. Theory Into Practice, 53(4), 278-285. http://dx.doi.org/10.1080/00405841.2014.947219

Hymel, S., Rocke-Henderson, N., \& Bonanno, R. A. (2005). Moral disengagement: A framework for understanding bullying among adolescents. In O. Aluede, A. G. McEachern, \& M. C. Kenny (Eds.), Peer victimization in schools: An international perspective (Vol. 8, pp. 1-11). New Delhi: Kamla Raj Enterprises.

Hymel, S., Schonert-Reichl, K. A., Bonnano, R., Vaillancourt, T., \& Rocke Henderson, N. (2010). Bullying and morality. Handbook of bullying in schools: An international perspective, 101-118. http://dx.doi.org/ 10.4324/9780203864968

Inverarity, J. (1980). Theories of the Political Creatian of Deviance: Legacies of Conflict Theory, Marx, and Durkheim. In P. Lauderdale (Ed.), A political analysis of deviance (pp. 175-219). Minneapolis: University of Minnesota Press.

Javeline, D. (2003). The Role of Blame in Collective Action: Evidence from Russia. American Political Science Review, 97(01), 107-121. http://dx.doi.org/10.1017/S0003055403000558

Jetten, J., \& Hornsey, M. J. (2014). Deviance and dissent in groups. Annual review of psychology, 65, 461485. http://dx.doi.org/10.1146/annurev-psych-010213-115151

Krug, E. G., Dahlberg, L. L., Mercy, J. A., Zwi, A. B., \& Lozano, R. (2002). World health report on violence and health. Geneva: World Health Organization.

Marques, A. G., Pinto, I. R., Leite, A. C., Randsley de Moura, G., Van Prooijen, J.-W., \& Marques, J. M. (under review). "Your past counts": Perceived (il)legitimacy as a criterion for reacting to transgressive leaders.

Marques, J. M., Abrams, D., Páez, D., \& Hogg, M. A. (2001). Social categorization, social identification, and rejection of deviant group members. Blackwell handbook of social psychology: Group processes, 400-424. http://dx.doi.org/10.1002/9780470998458.ch17

Marques, J. M., Abrams, D., Páez, D., \& Martinez-Taboada, C. (1998). The role of categorization and ingroup norms in judgments of groups and their members. Journal of Personality and Social Psychology, 75(4), 976. http://dx.doi.org/10.1037/0022-3514.75.4.976

Marques, J. M., Abrams, D., \& Serôdio, R. G. (2001). Being better by being right: Subjective group dynamics and derogation of in-group deviants when generic norms are undermined. Journal of Personality and Social Psychology, 81(3), 436-447. http://dx.doi.org/10.1037/0022-3514.81.3.436

Marques, J. M., \& Páez, D. (2008). Dynamique de groupes subjective: un cadre théorique pour l'effet brebis galeuse. Bilans et perspectives en psychologie sociale (Série $n^{\circ}$ 2, pp. 71-115). Grenoble: Presses Universitaires de Grenoble.

Marques, J. M., Yzerbyt, V. Y., \& Leyens, J. P. (1988). The "black sheep effect": Extremity of judgments towards ingroup members as a function of group identification. European Journal of Social Psychology, 18(1), 1-16. http://dx.doi.org/10.1002/ejsp.2420180102

Matos, M. G. d., Simões, C., Camacho, I., Reis, M., \& Equipa-Aventura-Social. (2015). A saúde dos adolescentes portugueses em tempos de recessão - Dados nacionais do estudo HBSC de 2014. Lisboa: FMH/ Universidade de Lisboa.

Obermann, M.-L. (2011). Moral Disengagement Among Bystanders to School Bullying. Journal of School Violence, 10(3), 239-257. http://dx.doi.org/10.1080/15388220.2011.578276

Olweus, D. (1978). Aggression in the schools: Bullies and whipping boys. Washington, DC: Hemisphere Press (Wiley.

Olweus, D. (1991). Bully/victim problems among schoolchildren: Basic facts and effects of a school based intervention program (Vol. 17). New Jersey: Lawrence Erlbaum Associates.

Olweus, D. (1994). Bullying at School. In L. R. Huesmann (Ed.), Aggressive Behavior: Current Perspectives (pp. 97-130). Boston, MA: Springer US.

Pinto, I. R., Marques, J. M., Levine, J. M., \& Abrams, D. (2010). Membership status and subjective group dynamics: Who triggers the black sheep effect? Journal of Personality and Social Psychology, 99(1), 107-119. http://dx.doi.org/10.1037/a0018187

Pinto, I. R., Marques, J. M., Levine, J. M., \& Abrams, D. (in press). Membership role and Subjective Group Dynamics: Impact on evaluative intragroup differentiation and commitment to prescriptive norms. Group Processes \& Intergroup Relations.

Pinto, I. R., Marques, J. M., \& Páez, D. (2015). National identification as a function of perceived social control: A subjective group dynamics analysis. Group Processes \& Intergroup Relations. http://dx.doi.org/10.1177/1368430215577225 
Postmes, T. (2009). The psychological dimensions of collective acfion, online. In A. Joinson, K. McKenna, T. Postmes, \& U.-D. Reips (Eds.), The Oxford Handbook of Internet Psychology (pp. 165-184). Oxford: Oxford University Press.

Quigley, B. M., \& Tedeschi, J. T. (1996). Mediating Effects of Blame Attributions on Feelings of Anger. Personality and Social Psychology Bulletin, 22(12), 1280-1288. http://dx.doi.org/10.1177/01461672962212008

Rigby, K. (2003). Consequences of Bullying in Schools. Canadian Journal of Psychiatry, 48(9), 583. http://dx.doi.org/ 10.1177/070674370304800904

Sani, F., Bowe, M., Herrera, M., Manna, C., Cossa, T., Miao, X., \& Zhou, Y. (2007). Perceived collective continuity: seeing groups as entities that move through time. European Journal of Social Psychology, 37(6), 1118-1134. http://dx.doi.org/10.1002/ejsp.430

Simon, B., \& Klandermans, B. (2001). Politicized collective identity: A social psychological analysis. American psychologist, 56(4), 319-331. http://dx.doi.org/10.1037/0003-066X.56.4.319

Smith, P. K., Pepler, D., \& Rigby, K. (2004). Bullying in schools: How successful can interventions be? : Cambridge University Press.

Smokowski, P. R., \& Kopasz, K. H. (2005). Bullying in School: An Overview of Types, Effects, Family Characteristics, and Intervention Strategies. Children \& Schools, 27(2), 101-110. http://dx.doi.org/10.1093/cs/27.2.101

Spears, R., \& Postmes, T. (2015). Group Identity, Social Influence, and Collective Action Online. In S. S. Sundar (Ed.), The Handbook of the Psychology of Communication Technology, (pp. 23-46). Oxford: John Wiley \& Sons.

Strelan, P., \& van Prooijen, J.-W. (2013). Retribution and forgiveness: The healing effects of punishing for just deserts. European Journal of Social Psychology, 43(6), 544-553. http://dx.doi.org/10.1002/ejsp.1964

Swann, W. B. J., Gómez, Á., Seyle, D. C., Morales, J. F., \& Huici, C. (2009). Identity fusion: The interplay of personal and social identities in extreme group behavior. Journal of Personality and Social Psychology, 96(5), 995-1011. http://dx.doi.org/10.1037/a0013668

Swearer, S. M., \& Doll, B. (2001). Bullying in schools: An ecological framework. Journal of Emotional Abuse, 2(2-3), 7-23. http://dx.doi.org/10.1300/J135v02n02_02

Tausch, N., Becker, J. C., Spears, R., Christ, O., Saab, R., Singh, P., \& Siddiqui, R. N. (2011). Explaining radical group behavior: Developing emotion and efficacy routes to normative and nonnormative collective action. Journal of Personality and Social Psychology, 101(1), 129-148. http://dx.doi.org/10.1037/a0022728

Theriot, M. T., Dulmus, C. N., Sowers, K. M., \& Johnson, T. K. (2005). Factors relating to self-identification among bullying victims. Children and Youth Services Review, 27(9), 979-994. http://dx.doi.org/10.1016/j.childyouth.2004.12.024

Thornberg, R., \& Jungert, T. (2013). Bystander behavior in bullying situations: Basic moral sensitivity, moral disengagement and defender self-efficacy. Journal of Adolescence, 36(3), 475-483. http://dx.doi.org/10.1016/j.adolescence.2013.02.003

van Stekelenburg, J., Klandermans, B., \& van Dijk, W. W. (2011). Combining motivations and emotion: The motivational dynamics of protest participation. Revista de Psicología Social, 26(1), 91-104. http://dx.doi.org/10.1174/021347411794078426

van Zomeren, M., Postmes, T., \& Spears, R. (2008). Toward an integrative social identity model of collective action: A quantitative research synthesis of three socio-psychological perspectives. Psychological Bulletin, 134(4), 504-535. http://dx.doi.org/10.1037/0033-2909.134.4.504

Vernberg, E., \& Biggs, B. (2010). Preventing and treating bullying and victimization: Oxford University Press.

Historial do artigo

Recebido 29/04/2016

Aceite $\quad 09 / 01 / 2017$

Publicado 11/2017 